\title{
Teaching Reform and Exploration of "Power Electronic Technology” Course Based on Project Teaching Method
}

\author{
Zheng Huang \\ Electrical Engineering College \\ Guizhou Institute of Technology \\ Guiyang 55003, China \\ huangz888@163.com
}

\begin{abstract}
Power Electronics Technology Course is an important basic course for electrical engineering and automation. In order to adapt to the rapid development of power electronics technology, deepen the reform of education and teaching, aiming at the problem that the practical ability of the students cannot be improved in the traditional teaching; this paper explores the power electronics technology teaching on the basis of project teaching method. Teaching practice shows that the power electronic technology based on project teaching has enhanced the students' learning interest and had a certain positive significance for students' innovation ability and engineering consciousness.
\end{abstract}

Keywords-Power electronic technology; Teaching Quality; Teaching reform

\section{INTRODUCTION}

"Power electronic technology" course is a very important professional basic course of electrical engineering and automation. It is an electronic technology which takes the electric energy as the research object, which uses a variety of power electronic devices on the voltage, current, waveform and frequency conversion and control of science. The knowledge system of this course mainly includes three modules of power device, converter circuit and control technology, as shown in Table1. It is an interdisciplinary subject covering three major electrical engineering disciplines: electricity, electronics and control.

TABLE I. "POWER ELECTRONICS TECHNOLOGY" TEACHING CONTENT MODULE

\begin{tabular}{|l|l|l|}
\hline Module & $\begin{array}{l}\text { Main teaching } \\
\text { contents }\end{array}$ & Teaching requirements \\
\hline Power devices & $\begin{array}{l}\text { Semi controlled device, } \\
\text { non-controllable device } \\
\text { and full control device }\end{array}$ & $\begin{array}{l}\text { Working principle, } \\
\text { parameter characteristic, } \\
\text { using method, driving } \\
\text { and protecting }\end{array}$ \\
\hline Converter circuits & $\begin{array}{l}\text { Rectifier, inverter, DC - } \\
\text { DC converter circuit, } \\
\text { AC - AC converter } \\
\text { circuit }\end{array}$ & $\begin{array}{l}\text { Can draw waveform, can } \\
\text { analyze, can calculate, } \\
\text { can choose }\end{array}$ \\
\hline Control technology & $\begin{array}{l}\text { SPWM control } \\
\text { technology, soft } \\
\text { switching technology }\end{array}$ & $\begin{array}{l}\text { SPWM inverter, } \\
\text { switching power supply, } \\
\text { soft switching } \\
\text { applications }\end{array}$ \\
\hline
\end{tabular}

The power device is the foundation in the teaching content of power electronic technology course, which focuses on the principles, parameters, drive and protection circuits of semicontrolled devices, uncontrolled devices and full control devices [1-3]. The typical converter circuit is the main body, which mainly focuses on the four basic transformation circuits, which are rectifier, inverter, DC converter and AC converter. The control part requires the student to master SPWM control technology and the soft switch technology principle and the application and so on.

With the rapid development of electric power industry and the deepening of education and teaching reform, there is a big gap between the application of power electronics technology and personnel training. There is much needed reform and construction in the course of power electronic technology. Such as: the theory course teaching and practice course teaching is out of touch, the practice teaching is in the subordinate position with respect to the theory teaching, comprehensive test and innovative test are less in the students' experiments. This causes the student innovation ability to be insufficient, the engineering consciousness is weak and so on. In view of the advantages of the project teaching method, the project teaching method is introduced into the teaching of power electronic technology course.

\section{PROJECT TEACHING METHOD}

"Project teaching" is the teaching activity by implementing a complete project. Its purpose is to organically combine theory and practice in the classroom teaching, fully explore the creative potential of students, and improve the students' comprehensive ability to solve practical problems.

The key to the project teaching is to design and develop a project task according to the teaching task and the goal. Its teaching content is based on the actual work flow as the carrier, through students' own practice to realize the actual work process, to deepen the understanding of the knowledge of students. The teacher as the guide of the learning process only directs students' research methods.

The project-oriented teaching of the power electronics technology curriculum demands to break the curriculum structure with the knowledge point as the system. It uses some 
specific projects to derive the knowledge, and guide students to learn, and then inspire students to use the knowledge and skills to solve a problem. Through the guidance of teachers, students in the implementation process of the project is more able to develop students' practical ability, analytical ability, ability to cooperate and other important ability to achieve teaching objectives.

\section{THE IMPLEMENTATION PLAN OF PROJECT TEACHING METHOD}

In view of the current problems in the teaching of power electronics, we propose a project-based teaching reform program. The implementation of teaching can be divided into: to determine the project, develop plans, the implementation of the project, the results of inspection and summary feedback as shown in Fig. 1.

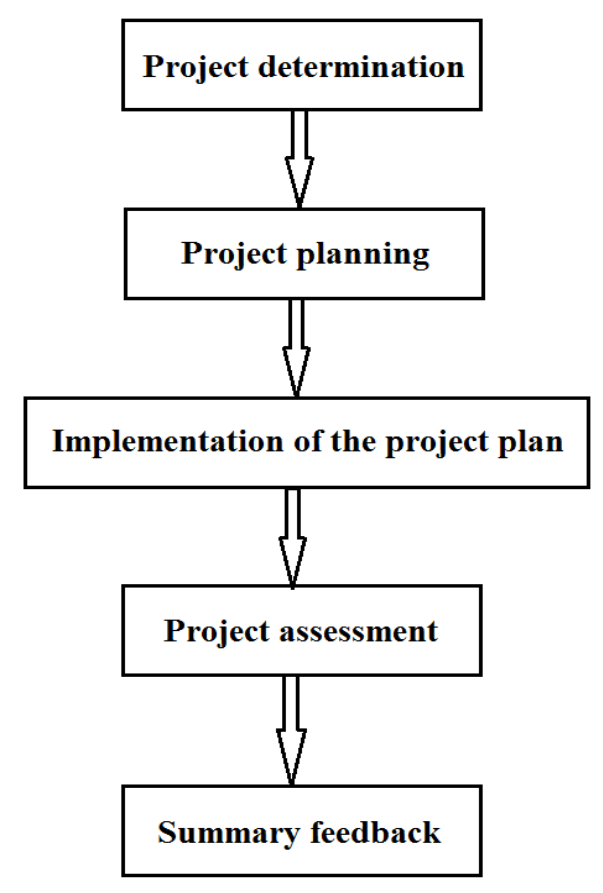

Fig. 1. Project-based teaching flow chart

\section{A. Project determination.}

How to use the same time teaching methods to better achieve the teaching objectives, the selection of the project is the key. Teachers should be more contact with enterprises to understand the practical application of the subject and the latest developments, and closely around their own teaching objectives, to develop teaching projects appropriately [4]. A total of 5 projects were designed for our power electronics technology courses as shown in Table 2. They are the design of thyristor dimming lamp circuit, design of DC motor speed regulating control circuit, design of stepless speed regulator for electric fan, design of Switching Power Supply Circuit, and design of frequency converter, respectively. In the course of implementing each project, students build a complete concept of power electronics devices as a whole. They experience the complete installation and commissioning process of power electronic equipment, improve the students' comprehensive application ability, and lay a solid foundation for students to develop application system in the future.

TABLE II. THE PRACTICAL PROJECT OF POWER ELECTRONIC TECHNOLOGY CURRICULUM

\begin{tabular}{|c|l|l|}
\hline $\begin{array}{c}\text { Serial } \\
\text { number }\end{array}$ & project name & Project requirements \\
\hline $\mathbf{1}$ & $\begin{array}{l}\text { design of thyristor } \\
\text { dimming lamp circuit }\end{array}$ & $\begin{array}{l}\text { To master the structure and working } \\
\text { principle of thyristor and single junction } \\
\text { transistor, To understand the } \\
\text { composition of the trigger circuit and } \\
\text { the working principle and Realization of } \\
\text { the single phase controlled rectifier } \\
\text { circuit }\end{array}$ \\
\hline $\mathbf{2}$ & $\begin{array}{l}\text { design of DC motor } \\
\text { speed regulating } \\
\text { control circuit }\end{array}$ & $\begin{array}{l}\text { To master the working principle and } \\
\text { Realization of inverter circuit }\end{array}$ \\
\hline $\mathbf{3}$ & $\begin{array}{l}\text { design of stepless } \\
\text { speed regulator for } \\
\text { electric fan }\end{array}$ & $\begin{array}{l}\text { To master the working principle and } \\
\text { Realization of the AC voltage regulation } \\
\text { circuit composed of two way thyristor }\end{array}$ \\
\hline $\mathbf{4}$ & $\begin{array}{l}\text { design of Switching } \\
\text { Power Supply Circuit } \\
\text { chopper circuit of MOSFET or GTR } \\
\text { switch device, Familiar with switching } \\
\text { power supply circuit wiring and } \\
\text { debugging }\end{array}$ \\
\hline $\mathbf{5}$ & $\begin{array}{l}\text { design of frequency } \\
\text { converter }\end{array}$ & $\begin{array}{l}\text { To master the principle of the frequency } \\
\text { conversion circuit and the design of the } \\
\text { governor. }\end{array}$ \\
\hline
\end{tabular}

\section{B. project planning.}

Through the teacher's narration, the students work out the project work plan, determine the work steps and procedures, and eventually get the teacher's approval. In this process, teachers should guide the students to think in the established direction, to develop a practical plan, in essence, which is a process of imparting knowledge.

\section{Implementation of the project plan}

After the task is determined, the students analyze the project and implement the project while learning the theory course. Clear what the project to solve the problem, where the key, the project to use what knowledge points. At this time, students take the initiative to absorb knowledge, actively collect information, take the initiative to analyze and solve problems. They become the protagonist of teaching, and teachers are converted to guide and service. Guide the students think in the established direction and implementation. In the course of the implementation of the project, it makes students not only to learn the theoretical knowledge, but also contact with the practical application. Students can understand the importance of power electronics technology in industry and life and a variety of applications.

\section{Project assessment and summary feedback}

After the completion of the project task, the teacher will check whether the project operation results meet the design requirements. Holding the project report meeting, each group report the design ideas, the key to the realization of the method, the hardware system design methods, problems and improvement measures. 


\section{ASSESSMENT LINKS}

Project oriented teaching needs to change the traditional teaching methods in a test set of the results of the assessment methods, the use of practice and theoretical examination combined with the examination, which accounted for $70 \%$ of the practice, theoretical examination accounted for $30 \%$. The practice assessment includes the study attitude, the work and the reply result. Theoretical examination can take open-book examination form. Because in practice, engineers can always access the relevant information, so there is no need to require students to rote. The examination paper not only examines students 'knowledge of software and hardware, but also examines the students' ability to analyze and judge common faults.

\section{CONCLUSIONS}

This kind of power electronic technology project teaching method provides to students with a good practical space. It can attract students' interest and improve students' learning enthusiasm and initiative. The student-centered teaching method and the guidance of students' teaching methods not only improve students' practical ability, but also improve students' ability of discovering problems, analyzing problems and solving problems, and improving the teaching quality.

\section{ACKNOWLEDGEMENT}

This research was financially supported by Guizhou province colleges and universities teaching contents and curriculum system reform project (Grant No. 201437802) and the key reform projects of Guizhou institute of technology (Grant No. 20131007)

\section{REFERENCES}

[1] Rong Jun, Ll Yi ming. The Application of Research Project in College Classroom Teaching [J]. JOURNAL OF EEE2013, (35)74-76.

[2] $\mathrm{Li} \mathrm{Xu}$ chun, Wang Chun feng. Innovating practical teaching and improving teaching effects of power electronics technology basic course [J]. Experimental Technology and Management2012, (29)11-13.

[3] Xia Mei juan, Ll Wei xiang. The experience in the teaching of Power Electronics[J]. Science\&Technology information2009, (31)901-903.

[4] Jiang Wei, Mo Yue ping. Teaching Mode of Power Electronics Technology Course[J]. 2013, (35)44-47. 